\title{
PELATIHAN APLIKASI MARKETPLACE BERBASIS MOBILE UNTUK KADER PKK KECAMATAN GAMBIR
}

\section{Engelin Shintadewi Julian ${ }^{1}$, Kiki Prawiroredjo ${ }^{2}$, Laser Narindro ${ }^{3}$, Gunawan Tjahjadi ${ }^{4}$ dan Faishal Erlangga ${ }^{5}$}

\author{
${ }^{1}$ Jurusan Teknik Elektro, Universitas Trisakti Jakarta \\ Email: eshintadewij@trisakti.ac.id \\ ${ }^{2}$ Jurusan Teknik Elektro, Universitas Trisakti Jakarta \\ Email: kiki.prawiroredjo@ trisakti.ac.id \\ ${ }^{3}$ Jurusan Teknik Informatika, Universitas Trisakti Jakarta \\ Email: laser.narindro@trisakti.ac.id \\ ${ }^{4}$ Jurusan Teknik Elektro, Universitas Trisakti Jakarta \\ Email: gunawandea@gmail.com \\ ${ }^{5}$ Jurusan Teknik Elektro, Universitas Trisakti Jakarta \\ Email: faishalerlangga11@gmail.com
}

\begin{abstract}
The use of information technology (IT) and internet networks is considered to be able to meet human needs in various sector. This is evidenced by the increasing availability of applications to be a media for data and information transactions about business by mobile-based applications that is marketplace. One indicator of the success of achieving a country's development is determined by human resources which can improve with education and workshop, event through by formal and non-formal channels. Role of Faculty of Industrial Technology, Trisakti University as an academic institution has carried out one of the functions of Tri Dharma of Higher Education that is community service activities which partnership with Family Welfare Empowerment cadres of Gambir District. The aims of this activity is to tarin for using marketplace based on mobile application to provide Family Welfare Empowerment cadres knowledge and skills to be able to promote and sell their products by online. These activity method uses are with seminar method for provide material about the introduction of the marketplace and workshop for use this application. From the results of this activity, it shows about participants satisfaction with score are $90 \%$ and level of benefit of this training materials provided are 90\%. The practical benefits form this training are to give knowledge for cadres for support the community to be able in improvement people's living standards.

Keywords: Community Service, Family Welfare Empowerment cadres, Marketplace, Mobile Application, Marketing Application Training
\end{abstract}

\begin{abstract}
ABSTRAK
Penerapan teknologi informasi (TI) dan jaringan internet dinilai dapat memenuhi kebutuhan manusia di berbagai bidang. Hal ini dibuktikan dengan semakin banyaknya ketersediaan aplikasi untuk dapat menjadi media transaksi data dan informasi tentang bisnis melalui aplikasi berbasis mobile berupa marketplace. Salah satu indikator keberhasilan pencapaian pembangunan suatu negara ditentukan oleh sumber daya manusia. Peningkatan kualitas sumber daya manusia dapat melalui pendidikan dan keterampilan baik yang dijalankan melalui jalur formal maupun non formal. Pada kesempatan kali ini, Fakultas Teknologi Industri Universitas Trisakti selaku institusi akademik telah melakukan salah satu fungsi dari Tri Dharma Perguruan Tinggi berupa kegiatan pengabdian kepada masyarakat (PKM) yang bermitra dengan kader Pemberdayaan Kesejahteraan Keluarga (PKK) Kecamatan Gambir. Pada kegiatan PKM tersebut, berisikan tentang pelatihan untuk penggunaan aplikasi marketplace berbasis aplikasi mobile yang bertujuan untuk memberikan pengetahuan dan keterampilan kepada kader PKK untuk dapat memasarkan dan menjual produk hasil karya masyarakat. Metode kegiatan PKM ini menggunakan metode seminar untuk pemberian materi tentang pengenalan marketplace dan pelatihan untuk menggunakan aplikasi tersebut. Dari hasil kegiatan PKM, menunjukan bahwa manfaat yang diberikan dari pelatihan tersebut, memperoleh nilai kepuasan dari peserta pelatihan sebesar $90 \%$ dan tingkat kebermanfaatan materi pelatihan yang diberikan yaitu sebesar $90 \%$. Adapun manfaat praktis yang didapatkan dari pelatihan ini, diharapkan dapat menjadi modal bagi para kader PKK dalam memberdayakan peran serta masyarakat sekitar untuk dapat meningkatkan taraf hidup masyarakat.
\end{abstract}

Kata kunci: PKM, Kader PKK, Marketplace, Aplikasi Mobile, Pelatihan Aplikasi Pemasaran

\section{PENDAHULUAN}

Salah satu indikator keberhasilan pencapaian pembangunan suatu negara ditentukan oleh sumber daya manusia. Peningkatan pendidikan dan keterampilan sumber daya manusia dapat dijalankan 
melalui jalur formal maupun non formal. Semakin tinggi jenjang pendidikan dan keterampilan yang dimiliki oleh sumber daya manusia semakin maju juga peradaban suatu Negara. Salah satu potensi yang dimiliki oleh sumber daya manusia pada suatu Negara adalah mampu mewujudkan peranannya di dalam kehidupan sosial bermasyarakat yang adaptif dan transformatif utnuk dapat mengelola kemampuan yang ada pada dirinya sendiri serta seluruh potensi yang dimiliki agar dapat tercapainya kesejahteraan pada kehidupannya dan berkelanjutan. Sumber daya manusia merupakan subyek yang aktif dan menentukan, bukan obyek yang pasif dan ditentukan sebagaimana kedua psikis yang dimilikinya Sumber Daya Manusia untuk melakukan berbagai kegiatan seperti bekerja yang dilakukan sebagai usaha untuk mewujudkan eksistensi organisasi atau perusahaan.

Salah satu upaya pemberdayaan masyarakat adalah melalui Gerakan Pemberdayaan Kesejahteraan Keluarga (PKK). Melalui pelatihan keterampilan PKK yang diberikan diharapkan mampu mengatasi permasalahan yang ada untuk dapat meningkatkan kualitas sumber daya manusia berdasarkan kompetensi yang dibutuhkan dan meningkatkan hubungan antara lembaga pendidikan dan kelompok masyarakat sehingga peran Pemerintah sebagai pengampu kepentingan masyarakat dapat lebih terbantu dan mempercepat target Pemerintah dalam mencapai pembangunan.

Udayana (2013) menjelaskan bahwa pada era teknologi jaringan komputer ditemukan, beberapa perusahaan berskala internasional, sudah menggunakan perdagangan elektronik (electronic commerce) untuk mengendalikan transaksi antarbisnis. Dengan adanya EDI (Electronic Data Interchange), perusahaan dapat melakukan pertukaran dokumen pada internal perusahaan itu sendiri dengan format yang telah ditentukan oleh perusahaan sesuai lingkup perusahaan tersebut. Hingga saat ini, penggunaan e-commerce yang diiringi dengan perkembangan teknologi jaringan (internet), dapat dimaksimalkan oleh semua perusahaan dalam skala besar, menengah dan kecil (Udayana, 2013).

Hal senada juga dijelaskan oleh Nemat (2011) melalui penelitiannya bahwa kemajuan teknologi baik infrastruktur jaringan maupun internet serta $w e b$, teknologi dapat meningkatkan kemampuan perusahaan dalam hal komunikasi bisnis dan dalam hal pengolahan informasi serta memberikan berbagai sumber daya lainnya yang berharga. Dalam menjawab tantangan yang ada pada saat ini, setiap perusahaan harus membuat lingkungan yang terintegrasi, memliki pandangan yang baik terhadap perangkat yang digunakan baik berupa perangkat keras maupun perangkat lunak, yang dapat mengendalikan informasi-informasi yang terkait dengan proses bisnis dan tidak bergantung pada tempat dan waktu tertentu. Peran front office pada setiap perusahaan dapat tergantikan dengan media aplikasi web yang tersedia pada perusahaan sehingga para konsumen tetap dapat menikmati jasa layanan yang disediakan oleh perusahaan kapanpun dan dimanapun (Nemat, 2011).

Menurut data yang disajikan pada penelitian yang dilakukan oleh Kesumah et al. (2019), sebesar $42 \%$ penjual yang melakukan transaksi e-commerce berusia 21-30 tahun dan penjual yang berusia 31-40 tahun memiliki persentase sebesar $38 \%$. Sedangkan sebesar $11 \%$ berusia 41 tahun ke atas. Berdasarkan survei yang telah dilakukan oleh lembaga riset Snapcart pada bulan Januari tahun 2018, menyatakan bahwa generasi millenial menjadi pembelanja terbanyak melalui $e$-commerce yaitu sebesar 50\% dengan rentang usia 25 hinga 34 tahun. Adapun jenis kelamin yang menjadi konsumen belanja online adalah wanita dengan jumlah yang mencapai 65\% (Kesumah et al., 2019)

Berdasarkan data dari Badan Pusat Statistik (BPS) (2019) menyatakan bahwa perkembangan e-commerce dalam 10 tahun terakhir di Indonesia mengalami peningkatan sebesar $17 \%$ dari jumlah e-commerce yang ada pada saat ini yaitu 26,2 juta unit. Indonesia 
menjadi target pembeli (pasar) untuk e-commerce. Hal tersebut juga didukung oleh data yang disajikan oleh Euromonitor, bahwa penjualan online di Indonesia mencapai angka US\$1,1 miliar dari tahun 2014 (Badan Pusat Statistik, 2019)

Dari data yang disajikan oleh iPrice yang bekerjasama dengan App Annie menjelaskan bahwa informasi pengguna aktif e-commerce di Indonesia dan Asia Tenggara dalam periode bulanan aplikasi pada Quartal ke 2 tahun 2020, didominasi oleh platform e-commerce Shopee dan Tokopedia di urutan pertama dan kedua. Data tersebut dapat dilihat pada Gambar 1.

\section{Gambar 1}

Jumlah Pengguna E-Commerce di Asia Tenggara dan Indonesia (Ip. Insight, 2020)

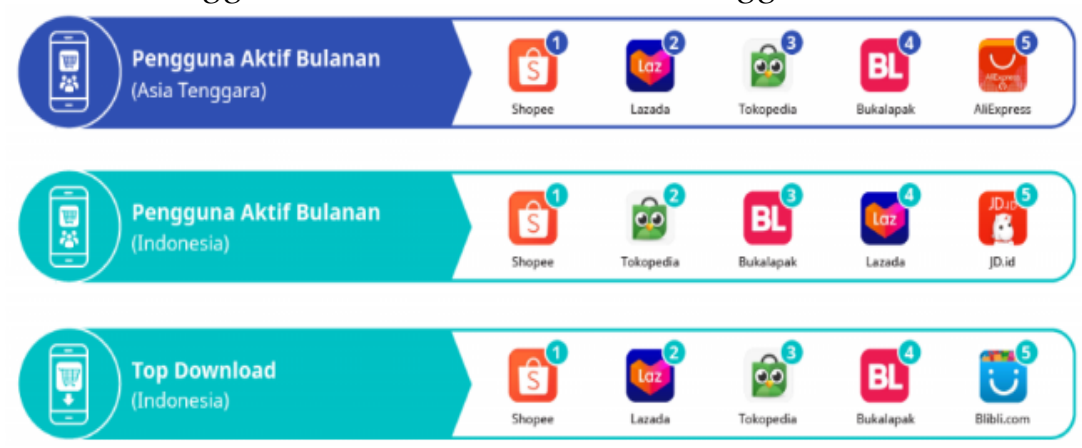

Dari pelaksanaan pelatihan marketplace yang telah dilakukan oleh Mujianto et al. (2020) menjelaskan bahwa hasil dari penerapan pelatihan penggunaan marketplace pada industri rumahan (home industry) yang berlokasi di desa Mojodanu, Kecamatan Ngusikan, Kabupaten Jombang, Jawa Timur dinilai membantu para pelaku usaha tersebut untuk dapat memperluas cakupan lokasi untuk dapat memasarkan produknya melalui media aplikasi marketplace sehingga dapat meningkatkan hasil produksi dan pendapatannya serta produk yang dihasilkan mampu bersaing dengan produk sejenis dan dapat dijadikan sebagai produk unggulan khas dari daerah tersebut (Mujianto et al., 2020)

Hal tersebut juga disampaikan oleh Rahmatika et al. (2020) yang menyatakan bahwa dengan mengoptimalkan peran aplikasi marketplace dapat memberikan dampak positif berupa peningkatan hasil penjualan produk dan mengurangi beban biaya pengeluaran. Adapun keuntungan yang didapat dari penggunaan aplikasi marketplace adalah berupa kemudahan dalam transaksi penjualan produk sehingga tidak memerlukan tempat untuk melakukan transaksi jual beli, mengurangi anggaran untuk promosi produk dan mengurangi beban anggaran untuk membayar gaji pegawai. Selain itu, penggunaan aplikasi marketplace ini dapat digunakan oleh siapa saja khususnya oleh para kader PKK sehingga pada saat menjalankan transaksi jual belinya dapat dilakukan kapan dan dimana saja tanpa harus mengorbankan kegiatan rutinitas rumah tangga yang harus dijalankan setiap harinya (Rahmatika et al., 2020)

Berdasarkan survei yang telah dilakukan sebelumnya, maka dapat diidentifikasi beberapa permasalahan yang dihadapi oleh kader PKK Kecamatan Gambir, yaitu sebagai berikut :

a. Diperlukan sebuah media transaksi online untuk dapat memasarkan dan menjual produk hasil karya masyarakat yang akan ditujukan kepada pelanggan; dan

b. Diperlukan pelatihan keterampilan dalam menggunakan aplikasi marketplace untuk dapat memasarkan dan menjual produk hasil karya masyarakat yang akan ditujukan kepada pelanggan yang diberikan kepada kader PKK Kecamatan Gambir. 
Berdasarkan identifikasi masalah yang telah dilakukan sebelumnya, dapat dirumuskan bahwa belum tersedianya media transaksi jual beli produk untuk dapat membantu para kader PKK Kecamatan Gambir. Dari penjelasan tersebut, maka melalui pelatihan keterampilan berupa penggunaan media pemasaran berbasis digital yaitu aplikasi marketplace berbasis aplikasi mobile yang dilakukan oleh kader PKK ini dapat dijadikan sebuah solusi mengatasi permasalahan yang dialami oleh kader PKK. Dari kegiatan tersebut, diharapkan dapat membantu para kader PKK pada Kecamatan Gambir untuk dapat meningkatkan keterampilan masyarakat dalam penggunaan platform marketplace sehingga diharapkan dari pelatihan keterampilan ini dapat memberikan dampak yang positif bagi para peserta pelatihan serta masyarakat dalam meningkatkan kesejahteraan hidupnya. Diharapkan dari pelatihan ini, cakupan kegiatannya tidak hanya sebatas dalam memberikan pelatihan saja akan tetapi dapat dilakukan kegiatan pendampingan terhadap kelompok usaha yang telah dibentuk oleh kader PKK Kecamatan Gambir melalui proses evaluasi terhadap capaian produktivitas dan penghasilan pada kelompok usaha binaan tersebut. Hal ini dapat menjadi nilai tambah yang dapat diberikan dari pelaksanaan kegiatan ini.

\section{METODE PELAKSANAAN PKM}

Metode kegiatan yang digunakan dalam kegiatan PKM ini adalah sosialisasi, pelatihan, pendampingan dan evaluasi. Pelaksanaan pengabdian dilakukan dengan tiga tahapan, di mana tahap pertama merupakan tahap persiapan. Pada tahap ini kelompok pengabdi melakukan suvei pendahuluan untuk mengetahui seberapa dalam pengetahuan kader PKK dalam menggunakan fungsi teknologi informasi berupa pembuatan aplikasi pemasaran berbasis web. Dalam tahap ini dicari permasalahan-permasalahan yang dihadapi oleh para kader PKK dalam meningkatkan kemampuan menghasilkan pengetahuan dan keterampilan. Tahap selanjutnya merupakan tahapan pelaksanaan kegiatan pengabdian. Dalam tahap ini pengabdi melakukan pendampingan berupa sosialiasi dan pelatihan dalam penggunaan penerapan teknologi informasi dan penggunaan platform e-commerce sebagai materi ajar. Tahap yang terakhir adalah tahap evaluasi. Pada tahap ini dilakukan evaluasi atas hasil yang telah dicapai oleh peserta pelatihan. Masukan dan perbaikan lebih lanjut dapat dilakukan pada tahap ini. Evaluasi diberikan dengan mengumpulkan data yang diperoleh dari data dampak yang diperoleh oleh para pemangku usaha berupa aspek pemahaman dan keterampilan. Data diambil dengan menyimpulkan pemahaman dan capaian transaksi penjualan dan peningkatan hasil produksi produk dan jasa serta layanan kepada pelanggan dengan metode ceramah dan dilanjutkan dengan tanya jawab dan diskusi, serta dari hasil pengembangan cakupan jangkauan segmentasi pasar yang diperoleh untuk para kader PKK.

Indikator ketercapaian tujuan pengabdian adalah bahwa terdapatnya peningkatan terhadap aspek pemahaman, pendapatan, partisipasi, produksi, pemasaran dan jangkauan, arti penting karya penerapan fungsi teknologi informasi untuk mendukung kegiatan belajar, arti penting peningkatan kualitas dan kuantitas karya berupa pengetahuan keterampilan yang dihasilkan. Sedang indikator ketercapaian untuk tujuan memberi bekal kemampuan bagi para pelaku usaha dalam mengembangkan terwujudnya segmentasi pasar yang akan dibentuk.

Pelaksanaan kegiatan Pengabdian Pada Masyarakat ini dikemas dengan menggunakan pendekatan workshop. Kegiatan dilakukan menggunakan metode ceramah, diskusi dan latihan. Adapun langkah-langkah dalam pelaksanaan kegiatan pengabdian ini adalah sebagai berikut:

Langkah 1: Peserta pelatihan diberikan dan diskusi tentang materi mengenai fungsi dan manfaat penerapan teknologi informasi dalam mendukung kegiatan usaha mereka dan akan dibagi menjadi 2 kelompok kader PKK yang sudah pernah melakukan pembuatan dengan yang belum pernah penggunaan platform e-commerce; 
Langkah 2 : Peserta berlatih untuk menerapkan penggunaan fungsi teknologi informasi dan penggunaan platform e-commerce untuk mendukung kegiatan pelatihan;

Langkah 3 : Peserta diberikan bimbingan dalam penerapan teknologi informasi dan penggunaan platform e-commerce untuk materi ajar yang diberikan;

Langkah 4 : Hasil karya penerapan fungsi teknologi informasi dan e-commerce berbasis web dikumpulkan dan dianalisis untuk diberikan masukan dan perbaikan lebih lanjut;

Langkah 5 : Evaluasi akhir merupakan evaluasi secara keseluruhan mulai dari tahap rekrutmen, pelatihan, dan praktek. Hasil evaluasi akhir digunakan untuk menentukan apakah peserta dapat dilepas menjadi kelompok mandiri atau dikembalikan ke pelatihan.

\section{HASIL DAN PEMBAHASAN}

Pelaksanaan PKM ini merupakan upaya peningkatan keterampilan untuk para kader PKK Kecamatan Gambir untuk dapat meningkatkan keterampilan dalam penggunaan aplikasi marketplace yang dapat dijadikan sebagai media promosi dan jual beli produk. Target khusus dari kegiatan PKM ini adalah perbaikan keterampilan untuk manajemen usaha melalui peningkatan strategi peningkatan keterampilan dalam menggunakan teknologi informasi dalam pembuatan aplikasi marketplace berbasis aplikasi mobile. Penyelesaian masalah pada aspek keterampilan dilakukan melalui penerapan teknologi tepat guna berwujud sebuah media untuk pemasaran dan transaksi jual beli produk. Solusi yang diberikan pada permasalahan aspek pemasaran adalah perluasan jangkauan pasar secara offline pada toko dan minimarket sekitar, serta pemanfaatan teknologi informasi pemasaran melalui aplikasi marketplace tersebut.

Strategi-strategi yang diterapkan pada pelatihan keterampilan ini berupa penerapan teknologi baru yaitu dengan cara mengendalikan faktor-faktor kunci (key factor) pada unit usaha yang telah dibuat oleh para kader PKK Kecamatan Gambir untuk dapat mengendalikan dan mengontrol proses bisnisnya. Adapun beberapa faktor yang harus diperhatikan pada saat menerapkan teknologi tersebut yaitu : (1) perlunya peningkatan daya saing yang kompetitif pada perusahaan; (2) mengefisiensikan waktu perusahaan untuk memasarkan produk yang dimiliki oleh perusahaan serta mengefektifkan pelayanan perusahaan; dan (3) meningkatkan pemasukan dan menekan pengeluaran perusahaan. Dalam hal ini teknologi internet selain dapat mengendalikan faktorfaktor kunci pada perusahaan juga dapat memberikan peluang-peluang bisnis baru untuk perusahaan. Teknologi web yang terintegrasi dan dapat diakses melalui internet menjadi peran penting dalam mendukung proses bisnis perusahaan dan memungkinkan perusahaan memasuki dan mengendalikan pasar dengan cepat dan tepat serta tanpa batasan geografis. Semua hal tersebut dapat terjadi pada ruang maya (cyber space). Dalam hal ini, organisasi dapat bersaing dengan kompetitornya pada dunia maya (virtual world). Perbandingan transaksi secara tradisional dan perdagangan elektronik dapat dilihat pada Tabel 1.

Dari pelaksanaan kegiatan pelatihan keterampilan penggunaan aplikasi marketplace yang telah dilakukan, akan menampilkan informasi terkait dampak yang diberikan melalui pelatihan untuk mengukur capaian kinerja pada pelatihan ini berupa pengetahuan dan keterampilan yang diperoleh oleh peserta pelatihan dalam melakukan promosi dan transaksi jual beli produknya serta kepuasan terhadap penyajian materi yang telah diberikan pada pelatihan. Adapun foto pada pelatihan keterampilan penggunaan marketplace menggunakan aplikasi Tokopedia untuk kader PKK Kecamatan Gambir dapat dilihat pada Gambar 2.

Dalam pelatihan tersebut peserta pelatihan menerapkan promosi dan menjual produk hasil karya mereka melalui marketplace yang telah tersedia kepada pasar. Sedangkan untuk interaksi antara penyaji materi dengan peserta pelatihan dapat dilakukan melalui metode, yaitu: 
a. Sesi tanya jawab melalui video conference; dan

b. Pengisian kuesioner untuk penilaian dampak yang diberikan melalui pelatihan keterampilan secara online.

\section{Tabel 1}

Perbandingan Media Perdagangan Tradisional dan Perdagangan Elektronik (Shivani, 2012)

Siklus Penjualan Perdagangan Tradisional (Menggunakan Perdagangan Elektronik

$$
\text { Berbagai Media) }
$$

Mencari informasi barang atau jasa yang diperlukan.

Memeriksa harga.

Memeriksa ketersediaan barang dan harganya.

Melakukan pemesanan.

Mengirimkan pesanan. MenKader PKKtkan pesanan.

Memeriksa barang di gudang.

Menjadwalkan pengiriman.

Membuat invoice.

Mengirimkan pesanan.

Konfirmasi pesanan.

Mengirim invoice (penyedia) danmenerima invoice (Pembayar).

Jadwal pembayaran.

Mengirim (pembayar) dan menerima (penyedia) bukti pembayaran.
Majalah, catalog, suratkabar, bentukbentuk tercetak.

Katalog tercetak.

Telpon, faksimili.

Surat, faksimili, dan bentukbentuk tercetak lainya.

Surat, faksimili

Manual

Bentuk tercetak, telpon, faksimili.

Bentuk tercetak.

Bentuk tercetak.

Pengirim.

Surat, telpon, atau faksimili.

Surat

Bentuk tercetak.

Surat.
(Menggunakan Media Tunggal)

Situs web.

Katalog on-line.

Situs web .

e-mail

e-mail, halaman web.

Basis data.

Basis data, halaman web.

Surat elektronik, basis data.

Basis data.

Pengirim.

Surat elektronik.

Surat elektronik, EDI.

Basis data, EDI.

\section{Gambar 2}

\section{Pelaksanaan Pelatihan Keterampilan Marketplace Secara Daring (On-line)}

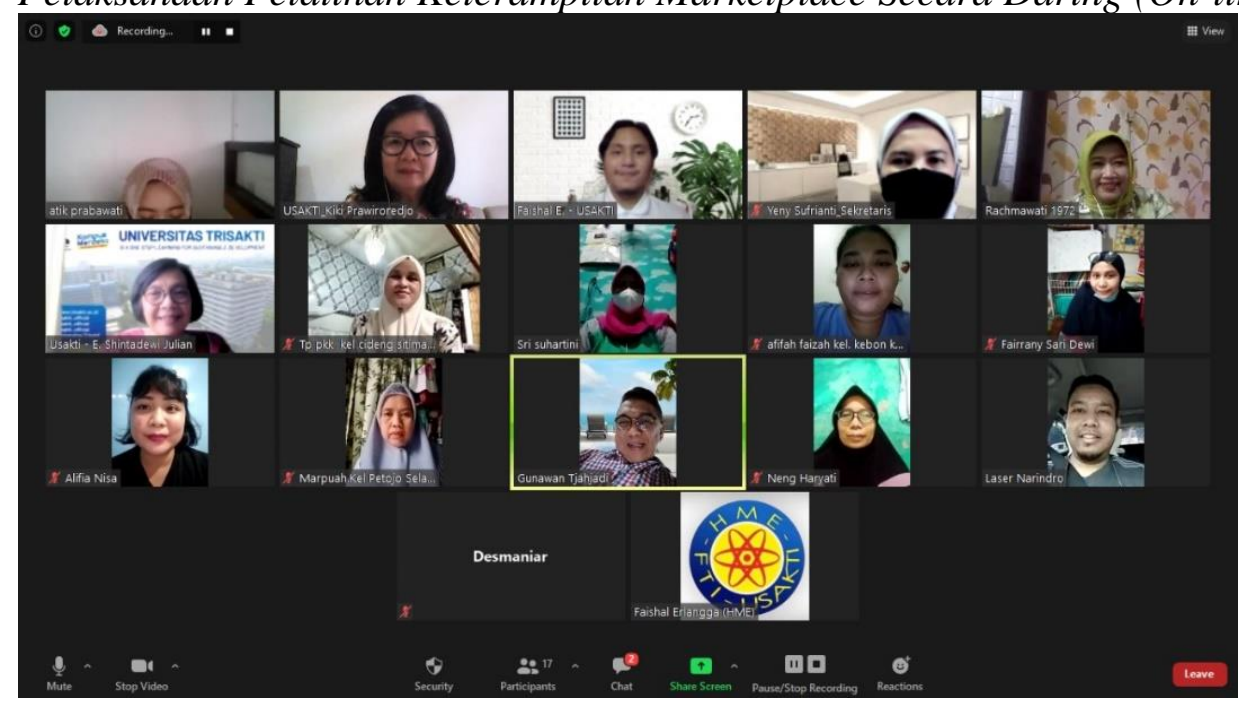


Untuk kategori penilaian pada kuesioner yang akan diisi oleh responden menggunakan metode skala linkert. Adapun dalam penentuan skala untuk jawaban yang diberikan dapat dinotasikan melalui penggunaan angka berupa angka 1 hingga 5 pada setiap pilihan jawaban. Dari penentuan skala penilaian tersebut dapat digunakan menjadi representasi untuk bobot penilaian jawaban yang telah diisi oleh peserta pelatihan. Penentuan bobot pada skala linkert dapat dilihat pada Tabel 2 .

Tabel 2

Likert Rating Scale (Effering, 2008)

\begin{tabular}{clll}
\hline Bobot & & \multicolumn{1}{c}{ Kriteria } \\
\hline 1 & Tidak Baik Sekali & Tidak Setuju Sekali & Tidak Yakin Sekali \\
2 & Kurang Baik & Kurang Setuju & Kurang Yakin \\
3 & Cukup Baik & Cukup Setuju & Cukup Yakin \\
4 & Baik & Setuju & Yakin \\
5 & Baik Sekali & Setuju Sekali & Yakin Sekali \\
\hline
\end{tabular}

Sedangkan untuk pengukuran kinerja ini dilakukan melalui pengisian kuesioner yang diisi oleh para peserta pelatihan yang dilakukan secara online. Adapun hasil dari kegiatan PKM ini dilakukan melalui perangkat penilaian kuesioner dan terbagi menjadi 2 bagian yaitu bagian pre test dan post tes untuk mengukur capaian kinerja pelatihan keterampilan ini. Untuk hasil penilaian melalui kuesioner pre test yang berisikan 5 pertanyaan dengan menggunakan metode skala linkert yang diisi oleh 10 repsonden yang merupakan kader PKK Kecamatan Gambir, Jakarta Pusat. Untuk gambar hasil kuesioner pre test tersebut dapat dilihat pada Gambar 3 hingga Gambar 5.

Dari hasil pengukuran kuesioner pre test dinilai bahwa peserta pelatihan belum memahami konsep e-commerce yang akan dijalankan untuk bidang usahanya. Sehingga dari data tersebut dapat diusulkan menjadi tema pelatihan pada kegiatan PKM kali ini yaitu berupa pelatihan pembuatan toko online pada salah satu platform e-commerce yang ingin dijalankannya. Adapun dampak dari kegiatan pelatihan keterampilan pembuatan toko online untuk peserta pelatihan dapat dilihat pada hasil kuesioner post test. Untuk kuesioner post test pada pelatihan keterampilan ini berisikan 7 pertanyaan dengan menggunakan metode skala linkert. Untuk melihat hasil pengisian kuesioner post test tersebut dapat dilihat pada Gambar 6 hingga Gambar 9.

Berdasarkan hasil pemaparan data kuesioner post test tersebut, dapat dijelaskan bahwa manfaat yang didapatkan dari pelaksanaan pelatihan keterampilan untuk penggunaan aplikasi marketplace ini mengalami peningkatan berupa pengetahuan untuk penerapan konsep marketplace pada usaha yang dijalani oleh peserta pelatihan serta memiliki tingkat kepuasan terhadap pelaksanaan pelatihan keterampilan ini yaitu sebesar sebesar $50 \%$ dengan kategori puas dan $40 \%$ dengan kategori sangat puas. Selain itu peserta pelatihan juga menilai bahwa kebermanfaat materi yang disajikan pada saat pelatihan mendapatkan tanggapan yang baik, dimana para peserta pelatihan menilai kebermanfaatan materi pelatihan untuk kemudiian hari yaitu sebesar $30 \%$ dengan kategori bermanfaat dan $60 \%$ dengan kategori sangat bemanfaat. Hal ini dinilai sesuai dengan tingkat kedalaman materi pelatihan yang telah diberikan kepada para peserta pelatihan serta manfaat teknis yang didapatkan dari pelatihan keterampilan ini.

Dari penjelasan tersebut, maka dapat disimpulkan bahwa penerapan pelatihan keterampilan untuk penggunaan aplikasi marketplace untuk media promosi dan transaksi jual beli dinilai produk yang disajikan oleh peserta pelatihan, dinilai efektif untuk diterapkan pada masyarakat sehingga tujuan praktis dari pelaksanaan kegiatan tersebut berupa pembekalan pengetahuan dan keterampilan yang diberikan kepada para kader PKK di Kecamatan Gambir dapat dijadikan sebagai pedoman dalam melakukan pendampingan selanjutnya kepada para pelaku usaha pada lingkungan Kecamatan 
Gambir. Hal ini bertujuan untuk dapat meningkatkan produktivitas dan penghasilan masyarakat yang berkolaborasi antara masyarakat dengan pihak lembaga sivitas akademika melalui Perguruan Tinggi.

\section{Gambar 3}

Pertanyaan Kuesioner Pre Test (a) Nomor 1 (b) Nomor 2

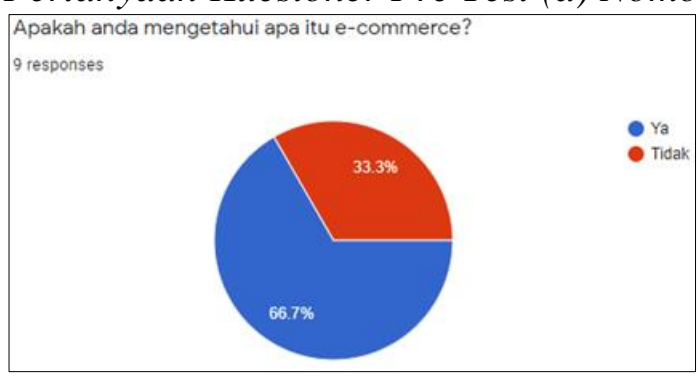

(a)

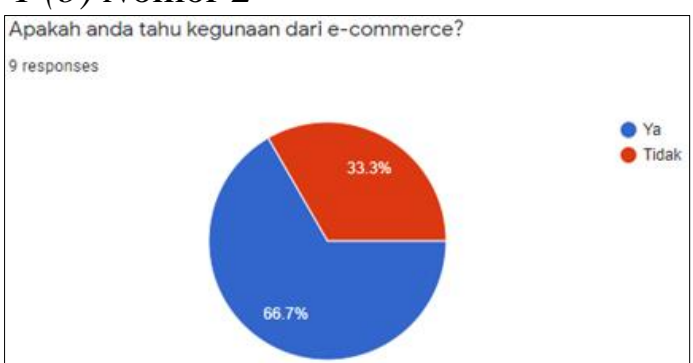

(b)

\section{Gambar 4}

Pertanyaan Kuesioner Pre Test (a) Nomor 3 (b) Nomor 4

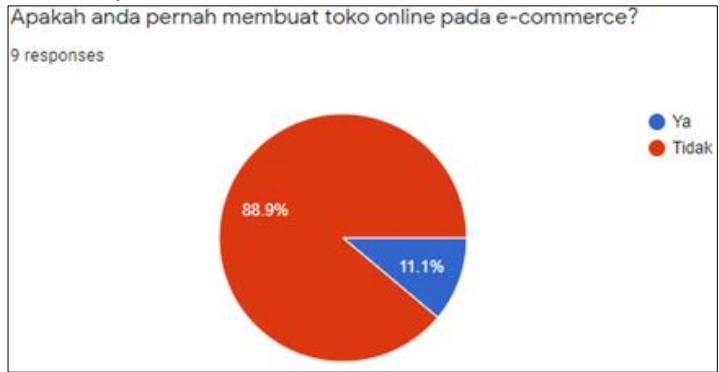

(a)

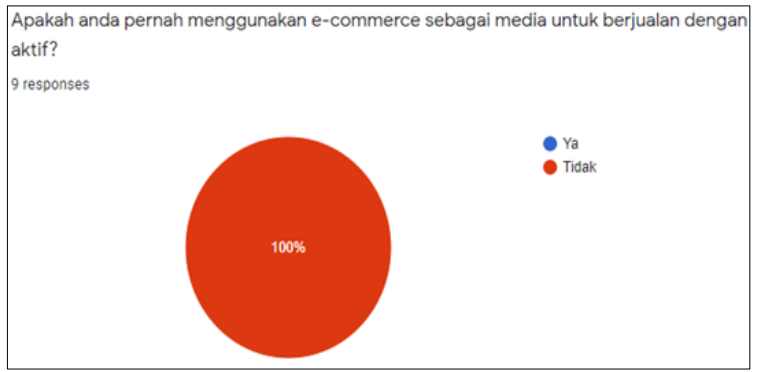

(b)

\section{Gambar 5}

\section{Pertanyaan Kuesioner Pre Test Nomor 5}

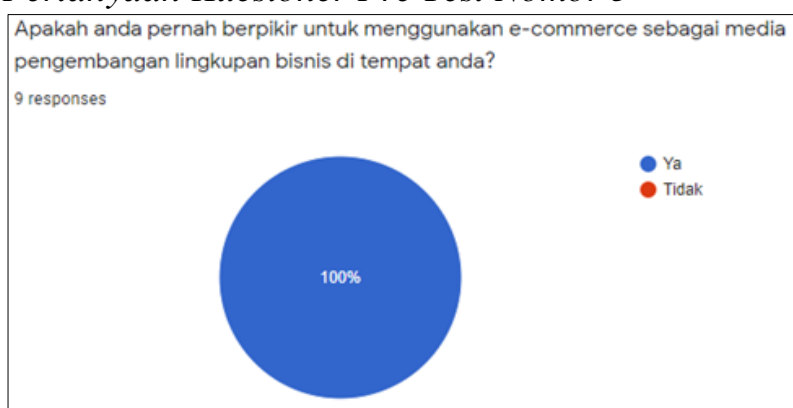

\section{Gambar 6}

Pertanyaan Kuesioner Post Test (a) Nomor 1 (b) Nomor 2

Apakah dengan mengikuti PKM ini anda sudah mengerti cara membuka toko online pada e-
commerce Tokopedia?
10 responses

(a)

(b) 


\section{Gambar 7}

Pertanyaan Kuesioner Post Test (a) Nomor 3 (b) Nomor 4

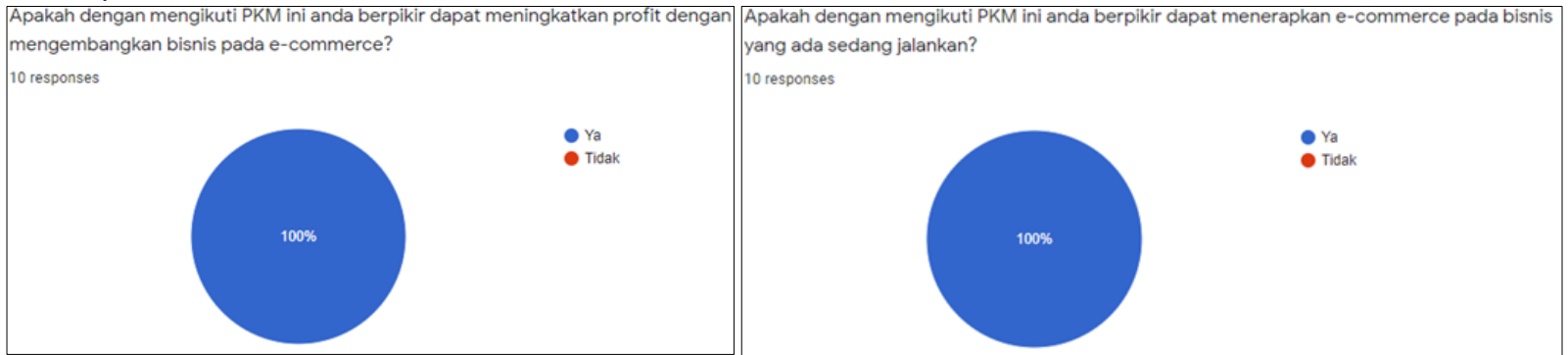

(a)

(b)

\section{Gambar 8}

Pertanyaan Kuesioner Post Test (a) Nomor 5 (b) Nomor 6

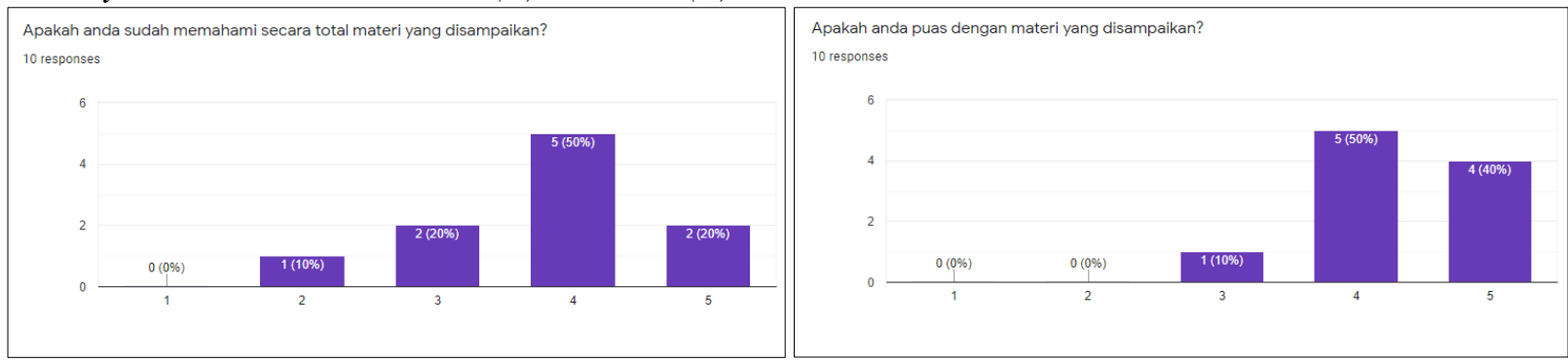

(a)

(b)

\section{Gambar 9}

Pertanyaan Kuesioner Post Test Nomor 7

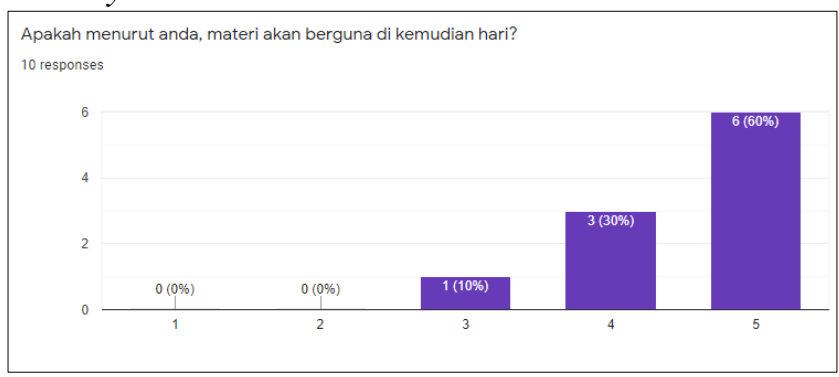

\section{KESIMPULAN DAN SARAN}

\subsection{Kesimpulan}

Berdasarkan hasil pemaparan pada hasil penjelasan tersebut, adapun kesimpulan yang dapat diberikan yaitu sebagai berikut:

1. Penerapan pelatihan keterampilan untuk penggunaan aplikasi marketplace untuk media promosi dan transaksi jual beli dinilai efektif untuk diterapkan pada masyarakat sehingga tujuan praktis dari pelaksanaan kegiatan ini berupa pembekalan keterampilan untuk para kader PKK pada Kecamatan Gambir dapat dijadikan sebagai pedoman dalam melakukan pendampingan kepada para pelaku usaha pada lingkungan tersebut untuk dapat meningkatkan produktivitas dan penghasilan masyarakat. Hal ini dibuktikan melalui penilaian terhadap tingkat kepuasan terhadap pelaksanaan pelatihan keterampilan ini yaitu sebesar sebesar $50 \%$ dengan kategori puas dan $40 \%$ dengan kategori sangat puas. Selain itu peserta pelatihan juga menilai bahwa kebermanfaat materi yang disajikan pada saat pelatihan mendapatkan tanggapan yang baik, dimana para peserta pelatihan menilai kebermanfaatan materi pelatihan untuk kemudiian hari yaitu sebesar $30 \%$ dengan kategori bermanfaat dan $60 \%$ dengan kategori sangat bemanfaat.; dan 
2. Dari pelaksanaan pelatihan keterampilan ini juga diharapkan dapat dilakukan secara berkelanjutan guna untuk dapat dilakukan ke dalam tahap berikutnya yaitu tahap pendampingan. Mengingat pelatihan ini merupakan tahap awal dari seluruh rangkaian kegiatan yang dapat diberikan dari pihak akademisi sebagai upaya pengembangan keilmuan dan teknologi tepat guna yang dapat diberikan kepada masyarakat. Penerapan kegiatan pengabdian kepada masyrakat ini dapat dijadikan sebagai forum komunikasi dan kolaborasi antara masyarakat dengan pihak Perguruan Tinggi.

\subsection{Saran}

Adapun saran yang dapat diberikan dari pembahasan di atas, adalah sebagai berikut:

1. Mengingat ini baru tahap awal dari fase kegitan PKM, maka diperlukan tahap monitoring dan evaluasi untuk pengembangan produk UKM yang dihasilkan oleh para Kader PKK Kecamatan Gambir, sehingga ada keberlanjutan dari sisi akademis dan teknis; dan

2. Hasil dari PKM ini dapat dijadikan dasar pertimbangan untuk para pemangku kepentingan dan pengambil kebijakan pada bidang pengembangan ekonomi kreatif untuk kader PKK Kecamatan Gambir agar dari laporan evaluasi kegiatan dapat dijadikan sebagai usulan dalam rencana strategis program kerja PKK ke depannya.

\section{Ucapan Terima Kasih (Acknowledgement)}

Kami mengucapkan terima kasih dan memberikan apresiasi kepada Lembaga Pengabdian Pada Masyarakat dan Fakultas Teknologi Induistri Universitas Trisakti untuk dukungan baik dari segi materi dan non materi yang diberikan kepada pelaksana kegiatan sehingga program Pengabdian Pada Masyarakat dengan judul "Pelatihan Keterampilan Penggunaan Aplikasi Marketplace Untuk Kader PKK Kecamatan Gambir" dapat terlaksana dengan baik.

\section{REFERENSI}

Udayana, A. (2013). E-commerce. https://adoc.pub/e-commerce-oleh-nama-ana-udayana-nimkelas-e-commerce 5si054.html.

Nemat, R. (2011). Taking a look at different types of e-commerce. World Appl. Program, 1, 100 104.

Kesumah, H., Alfatih, A., \& Meilinda, N. (2019). Efektivitas iklan tokopedia versi 'semua dimulai dari tokopedia' pada media televisi (studi pada mahasiswa indo global mandiri. https://repository.unsri.ac.id/11457/.

Badan Pusat Statistik. (2019). Statistik e-commerce 2019.

Ip. Insight. (2020). Peta e-commerce Indonesia. https://iprice.co.idinsights/mapo fecommerce.

Mujianto, A. H., Sucipto, H., Mashuri, C., Permadi, G. S., \& Vitadiar, T. Z. (2020). Implementasi online market place pada industri rumahan di desa mojodanu ngusikan jombang. ABIDUMASY J. Pengabdi. Kpd. Masy., 1(1), 13-23. doi: 10.33752/abidumasy.v1i1.651.

Rahmatika, R., Dhika, H., \& Isnain, N. (2020). Penerapan E-commerce pada kelompok PKK di Kelurahan Pabuaran - Cibinong. J. PkM Pengabdi. Kpd. Masy., 3(3), 218. doi: 10.30998/jurnalpkm.v3i3.4614.

Shivani, G. (2012). E-commerce: security challenges \& growth: an indian perspective. IJMRS'S Int. J. Manag. Sci. 